\title{
Aboveground Growth Response of Platanus orientalis to Porous Pavements
}

\author{
Justin Morgenroth and Rien Visser
}

\begin{abstract}
Integrating healthy, mature trees into paved urban environments is a challenging task for urban foresters, as impervious pavements are associated with reduced tree growth and survival. It is thought that porous pavements may alleviate this problem due to their permeability to air and water. The authors of the following study tested whether porous pavements affect tree growth relative to impervious pavements by measuring aboveground growth in trees treated with an augmented factorial arrangement of pavement profile designs and pavement types. Fifty oriental plane (Platanus orientalis) seedlings were evenly distributed to control plots or one of four treatments. Treated plots were characterized either by porous or impervious pavement pads measuring $2.3 \mathrm{~m} \times 2.3 \mathrm{~m}$, that were underlain either by fine sandy loam or a gravel base and compacted subgrade, reflecting two pavement profile designs. Results show stem height, diameter, and biomass increased as a result of porous pavements. Greater growth proffered by porous pavements was negated by profile designs including a compacted subgrade and gravel base. Finally, impervious pavements did not negatively influence tree growth, relative to control trees.

Key Words. Biomass; Oriental Plane; Permeable; Pervious; Road; Sidewalk; Soil Compaction; Street Tree.
\end{abstract}

The urban forest is a major infrastructure element, providing environmental, economic, and social benefits. Healthy, mature trees improve air and water quality (Xiao et al. 1998; Heckel 2004), moderate extreme temperatures (Long-Sheng et al. 1993), reduce energy consumption (McPherson 1994), increase real estate values (Anton 2005), provide wildlife habitat (Dunster 1998), and provide intangible benefits including aesthetic and recreational amenities. Street trees planted alongside roads and sidewalks are a major component of the urban forest. Street trees are subject to environmental stresses, both biotic and abiotic, which fluctuate and interact to affect plant function and growth. Furthermore, anthropogenic stresses compound the natural environmental stresses already imposed on trees. Buildings and pavements render ground surfaces impervious; stormwater management systems divert water away from soil and into designated reservoirs; soils are compacted to meet engineering standards; and trees are often planted in confined growing spaces. The additive effect of these and other factors is that urban trees have comparably shorter life spans and reduced annual growth than their forest-based conspecifics (Quigley 2004).

One defining characteristic of the urban environment is impervious pavement. This infrastructure element is used for roads, parking lots, and sidewalks. It is pervasive, and in some cases covers more than $50 \%$ of land surfaces (Ferguson 2005). Trees surrounded by pavements have their growing environment altered; soil chemistry and physics are both modified by overlying pavements (Craul 1985; Macdonald et al. 1993; Jim 1997; Celestian and Martin 2004), as are a number of localized atmospheric factors, such as surface temperature and vapor pressure deficit (Kjelgren and Montague 1998). This has led to speculation that pavements cause decreased growth, premature decline, and death (Kjelgren and Clark 1994; Iakovoglou et al. 2001; Schröder 2008).

The pavement profile for a load-bearing pavement will include, from bottom to top, compacted parent material (hereafter referred to as a subgrade), a gravel base, and typically, an impervious surface course. In contrast, the pavement profile design for non-load-bearing pavements may include only a surface course installed over a compacted subgrade. Surface courses such as concrete or asphalt, combine a well-graded mix of aggregates and a binder to maximize density and limit permeability. An alternative pavement type precludes the inclusion of fine aggregate and thus, results in a porous pavement. In contrast to impervious pavements, porous paving is characterized by a matrix of interconnected pores, which render it permeable to air and water. Porous pavements are generally perceived to promote tree growth and survival by enhancing moisture infiltration and increasing soil aeration (Tennis et al. 2004; Ferguson 2005). Theoretically, this is plausible, but these hypotheses have never been experimentally tested in a system including live trees. In the following experiment, this gap in knowledge is addressed by testing the effects of porous and impervious pavement profile designs on tree height, diameter, and aboveground biomass.

\section{METHODS}

\section{Study Site}

The experiment was located at the city council nursery in Christchurch (Lat: -43.493, Long: 172.437), the largest city in New Zealand's South Island. The top meter of soil is a fine sandy loam (Raeside 1974), and it overlies a 
deposit of sand and gravel, remnant from the alluvial outwash deposited by an ancient glacier (Brown and Weeber 1992).

The climate is temperate, and mean daily maximum temperatures range from c. $10^{\circ} \mathrm{C}$ in July to $21^{\circ} \mathrm{C}$ in January (McGann 1983). Occasional dry northwesterly winds occur during spring and summer, when temperatures can reach $30^{\circ} \mathrm{C}$ and relative humidity can drop to $20 \%-40 \%$ (McGann 1983). Rainfall ranges from $600-700 \mathrm{~mm}$ annually and is generally evenly distributed throughout the year, with a tendency for slightly higher early winter precipitation (McGann 1983).

\section{Experimental Design}

Chosen due to their wide-spread use as street trees, 50 one-year old, bare root oriental plane (Platanus orientalis) seedlings were randomly assigned to plots in an augmented factorial experiment consisting of controls and four treatments; trees were split evenly among treatments, such that ten replicates existed per treatment. Herbicide applications were used, as necessary, to limit weed competition in control plots, which were characterized by an exposed soil surface. In early August 2007, seedlings were planted at grade in undisturbed soil in plot centers and, in the case of treated trees, surrounded by concrete pavement pads, which had been installed in early July 2007 . The pavement treatments, measuring $2.3 \mathrm{~m} \times 2.3 \mathrm{~m}$ (with a $30 \mathrm{~cm}$ diameter circular cutout in the center), were based on the combination of pavement type (2 levels: porous, impervious) and pavement profile design (2 levels: +/subgrade compaction and gravel base). The resulting four treatments were impervious concrete pavement (IP), impervious concrete pavement with compacted subgrade and gravel base (IP+), porous concrete pavement (PP), and porous concrete pavement with compacted subgrade and gravel base ( $\mathrm{PP}+)$. The distinction between the two levels of pavement profile design is related to the preparation of the profile below the pavement surface course. In IP and PP plots, profile preparation was limited to leveling the topsoil with a $500 \mathrm{~kg}$ roller. In contrast, in IP+ and PP+ plots, topsoil was removed to a depth of $20 \mathrm{~cm}$, exposing the parent material which was termed the subgrade. Then, a $20 \mathrm{~cm}$ deep base layer of washed, uniformly graded, $20-40 \mathrm{~mm}$ gravel was placed in the hole and leveled with a $500 \mathrm{~kg}$ roller. The difference between the two levels of pavement profile design are thus related to the inclusion (or exclusion) of a gravel base and the soil strength of the subgrade. Soil penetration resistance was measured via a soil compaction meter (Spectrum Technologies, Inc., Plainfield, IL, U.S.) in accordance with ASAE Standard EP542 (2002). Penetration resistance values for the uppermost $30 \mathrm{~cm}$ of soil are measured by a load sensor and displayed in $\mathrm{kPa}$. Mean values differed significantly among treatments $(P<0.001)$ and were $892 \mathrm{kPa}$, $874 \mathrm{kPa}, 808 \mathrm{kPa}, 2458 \mathrm{kPa}$, and $2363 \mathrm{kPa}$ for control, IP, PP, IP+ and $\mathrm{PP}+$, respectively. Finally, IP and IP+ plots were overlaid by a standard impervious concrete, while $\mathrm{PP}$ and $\mathrm{PP}+$ were overlaid by a pervious concrete designed specifically for this experiment.

\section{Data Collection}

Initial height and diameter were measured at the time of planting, in August 2007, prior to the first growing season; subsequent measurements occurred at the end of spring in the first growing season (December 2007), as well as the end of the first (March 2008) and second (March 2009) complete growing seasons. Tree height was measured as the distance between the soil surface and the tip of the apical bud on the leader of each tree, while the diameter was calculated as the average of two measurements taken perpendicular to one another $10 \mathrm{~cm}$ above the soil surface. Mean initial tree height was $62 \mathrm{~cm}$ and initial trunk diameter was $6.7 \mathrm{~mm}$. Neither initial height $(P=0.663)$, nor diameter $(P=0.961)$ differed significantly among treatments. Height and diameter growth were measured as the absolute growth occurring over the duration of the experiment. On March 12, 2009, all trees were harvested at ground level. This plant material comprised aboveground biomass and was dried in a kiln at $70^{\circ} \mathrm{C}$ to constant weight (Nicholson 1984).

\section{Statistical Analysis}

One IP+ tree died between the first and second growing seasons and was thus excluded in all analyses. Stem height, diameter, and aboveground biomass were compared via one-way analysis of variance (ANOVA), using orthogonal, a priori, single degreeof-freedom contrasts to examine treatment effects, as well as interactions of interest (Marini 2003). Significant differences are reported for $P<0.05$. Analyses were performed using the R statistical package, version 2.8.1 (R Development Core Team 2008).

\section{RESULTS}

\section{Height Growth}

While height growth was dependent upon treatment $(P=$ 0.022 ), mean height growth of control trees was equivalent to all other treatments (Table 1, contrast 1), thus implying differences among the four pavement treatments. Alone, the pavement profile design had no effect on tree height, as the mean height growth of all PP and IP trees did not differ from all PP+ and IP+ trees (Table 1, contrast 2). Nevertheless, height was significantly affected by the interaction between pavement type and profile design (Table 1, contrast 4). Further investigation showed that without subgrade compaction or a gravel base, trees surrounded by porous paving grew approximately $205 \mathrm{~cm}$, while those surrounded by impervious paving grew only 160 $\mathrm{cm}$. However, in plots with a compacted subgrade and gravel base, a difference of less than $2 \mathrm{~cm}$ existed between trees surrounded by porous and impervious pavement (Figure 1).

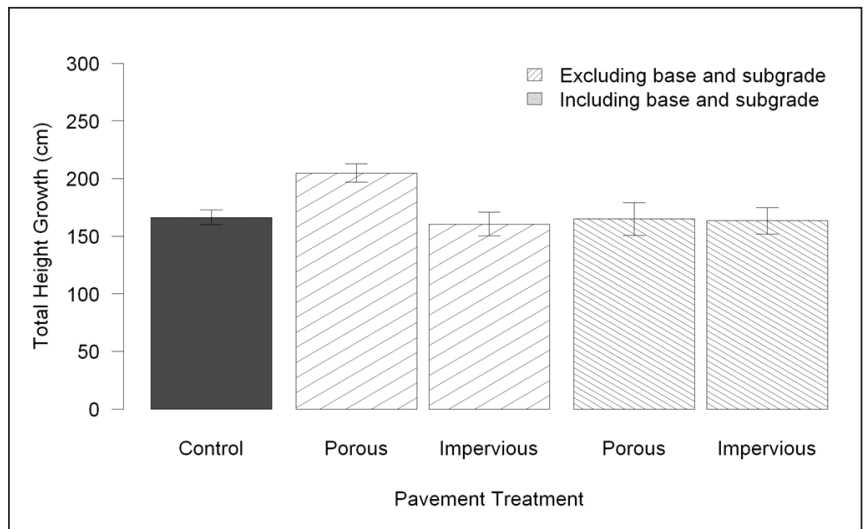

Figure 1. The effect of pavement type and profile design on mean height growth of Platanus orientalis relative to control plots characterized by bare soil. Values represent total growth following two growing seasons. Error bars represent one standard error. 
Table 1. Single degree-of-freedom contrasts comparing the effect of pavement type and profile design on total stem height and diameter growth, as well as aboveground biomass.

\begin{tabular}{|c|c|c|c|c|}
\hline Contrasts & $\mathrm{df}$ & $P_{\text {height }}$ & $P_{\text {diameter }}$ & $P_{\text {biomass }}$ \\
\hline 1. Control vs. all other treatments & 1 & 0.542 & $0.009 *$ & $0.007 *$ \\
\hline 2. Main effect (pavement profile design) & 1 & 0.083 & $0.001 *$ & $0.0003 *$ \\
\hline 3. Main effect (pavement type) & 1 & $0.033 *$ & $0.041 *$ & $0.004 *$ \\
\hline 4. Interaction (pavement profile design $\mathrm{x}$ pavement type) & 1 & $0.046^{*}$ & $0.015^{*}$ & $0.001 *$ \\
\hline
\end{tabular}

$* P<0.05$

\section{Diameter Growth}

Stem diameter growth was also dependent upon treatment $(P<$ $0.001)$. Unlike height growth results, the mean diameter growth for all pavement treatments exceeded that for control trees (Table 1, contrast 1). While the effect of pavement profile design and pavement type were both significant, diameter growth depended on their interaction (Table 1, contrast 4). Diameter growth gains provided by porous pavement were limited to plots without a gravel base and subgrade compaction, as pavement type did not effect change in IP+ or PP+ plots (Figure 2).

\section{Biomass}

Aboveground biomass was dependent on treatment $(P<0.001)$ (Figure 3). Mean biomass for control trees was lower than the mean of treated trees (Table 1, contrast 1). While both pavement type and profile design main effects were significant, these factors exhibited a strong interaction (Table 1, contrast 4). Pavement type had no effect in plots with a compacted subgrade and gravel base, but trees in PP plots had significantly greater shoot biomass than trees in IP plots (Figure 3 ).

\section{DISCUSSION}

Within the context and limitations of this experiment, the results show: 1) impervious pavements alone do not restrict or compromise tree growth, relative to control plots; and 2) relative to control plots and impervious pavements, porous pavements can improve tree growth, but only in the absence of a compacted subgrade and gravel base.

\section{Effect of Pavement on Tree Growth}

It's important to deconstruct pavements into their primary constituents, the pavement surface, and the underlying structural layers including a subbase, subgrade, and base. Many of the problems faced by street trees are generally ascribed to pavements without distinguishing between the surface or underlying structural layers. In the 1970s, it was commonly believed pavement surfaces caused reductions in soil moisture by precluding infiltration (Roberts 1977); however, more recent research has indicated that street trees may suffer from too much, rather than too little water (Berrang et al. 1985), though it's unclear whether this is due to the surface or underlying soil compaction. Pavement surfaces have also been said to increase air (Whitlow and Bassuk 1988) and soil (Graves 1994; Celestian and Martin 2004) temperatures above levels for optimal physiological function. Furthermore, soil compaction beneath pavements has been linked to poor plant performance (Smiley et al. 2006). As pavements are associated with soil moisture extremes, excessive soil and air temperature, and root-limiting soil compaction, it is easy to understand why decline in street trees is ascribed to pavements.

In spite of this, none of the pavement treatments in this experiment negatively influenced tree growth relative to controls. In fact,

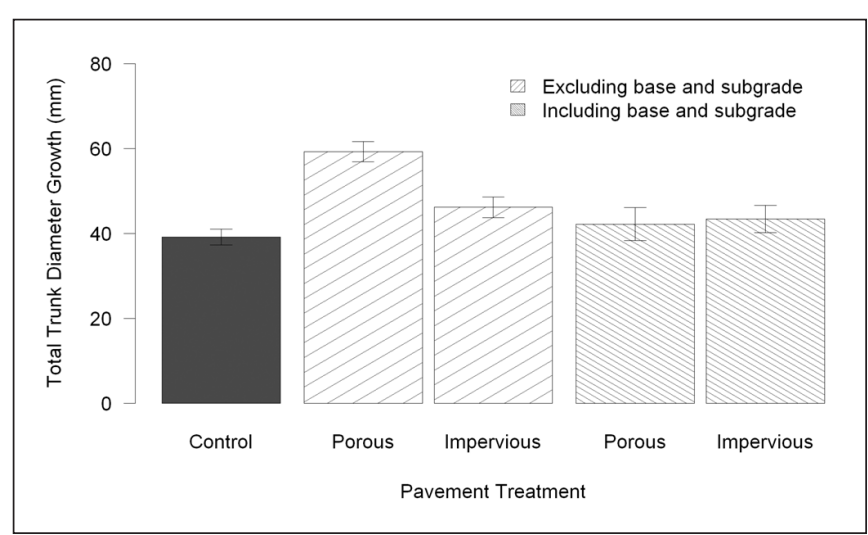

Figure 2. The effect of pavement type and profile design on mean trunk diameter growth of Platanus orientalis relative to control plots characterized by bare soil. Values represent total growth following two growing seasons. Error bars represent one standard error.

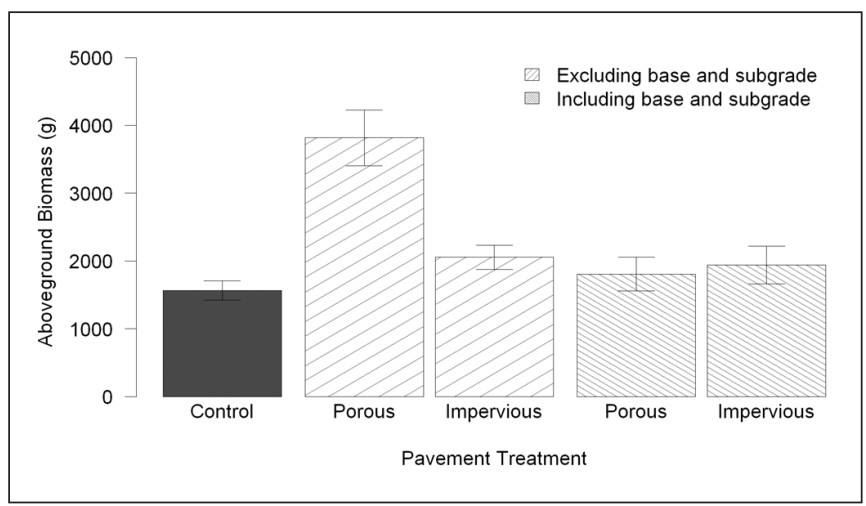

Figure 3. The effect of pavement type and profile design on mean shoot biomass of Platanus orientalis relative to control plots characterized by bare soil. Values represent total growth following two growing seasons. Error bars represent one standard error.

tree height, diameter, and aboveground biomass were equivalent, or greater, in pavement-treated trees relative to control trees (Table 1 , contrast 1 ). This suggests trees do not necessarily suffer from reduced growth and vigor as a direct result of overlying pavements. It is not disputed that street trees in paved areas are often associated with reduced growth rates and low survival, as this is well established (Gartner et al. 2002). However, pavements themselves are not necessarily the direct cause of tree decline. An alternative explanation is that street trees suffer from the compounding stresses often associated with pavements, such as restricted soil volume (Kopinga 1991), soil compaction (Philip and Azlin 2005), physical injuries to the stem and branches (Fostad and Pedersen 1997), air pollution (Su and Sun 2006), soil pollution via salt or other 
chemicals (Marosz and Nowak 2008), and soil moisture extremes (Berrang et al. 1985). These additional stresses were not measured in this experiment, except for soil compaction and soil moisture. The latter was measured as part of a larger experiment, and it was found that soil moisture beneath pavements consistently exceeded those in bare soil (Morgenroth and Buchan 2009). Given adequate soil moisture and the absence of many stresses known to afflict street trees, it is understandable why pavements alone produced no negative impacts on tree growth in this experiment.

\section{Effect of Porous Pavement on Tree Growth}

It has been suggested that porous pavements may play a role in improving tree growth by ameliorating underlying soil conditions (Ferguson 2005). This experiment confirmed tree growth can be improved by porous, rather than impervious pavement, but only in the absence of a compacted subgrade and a gravel base, where trees surrounded by porous pavements were taller and had greater stem diameter and aboveground biomass than trees surrounded by impervious pavement (Table 1, contrast 4).

It would be easy to suggest that differences in growth must be associated with the permeability of the porous pavement, and thus, higher soil moisture. However, Morgenroth and Buchan (2009) found that soil moisture did not differ beneath porous and impervious pavements. Therefore, other explanatory factors must be considered.

Knowing that increased growth occurred only in plots without a gravel base and compacted subgrade suggests that the benefits proffered by porous pavement are superseded by some factor associated with the profile design. One possibility is that soil compaction counteracted the effects of porous paving. Soil compaction is at odds with the requirements of trees, whereby highly compacted soils are known to negatively impact tree growth (Smith et al. 2001). In this experiment, soil penetration resistance in IP+ and PP+ plots was $2410 \mathrm{kPa}$. In contrast, soil in IP and PP plots had mean penetration resistance of only $841 \mathrm{kPa}$. In soils similar to those in this experiment, values between $2000 \mathrm{kPa}$ and $3000 \mathrm{kPa}$ are sufficient to hinder root development (Sinnett et al. 2008). Thus, it is likely the compacted subgrade restricted root development, thereby negating the positive effects of porous pavement exhibited in plots without a compacted subgrade and gravel base.

The theory that soil compaction negates the benefits provided by porous pavements could have critical implications for future porous pavement installations. The vast majority of pavements are designed to bear heavy loads and are thus underlain by highly compacted subgrade and base layers. Accordingly, the use of porous pavement for tree growth amelioration may be limited to areas such as sidewalks and low-use parking lots, unless steps are taken to minimize soil compaction. One way to minimize soil compaction is to use specially designed pavement profiles, whereby the pavements are engineered to withstand heavy loads, while avoiding soil compaction with the use of suspended pavements or accommodating compaction in soil design, such as with CU-Soil ${ }^{\mathrm{TM}}$. While these alternatives have been proven to perform as intended (Smiley et al. 2006; Buhler et al. 2007), their prevalence is presently restricted.

\section{CONCLUSION}

In summary, the present experiment revealed differences in tree growth resulting from differing pavement types and pro- file designs. Results indicate that pavements, in the absence of other stresses, do not cause reduced tree growth, even if the profile design includes a compacted subgrade and gravel base. It was also concluded that porous pavement could improve the aboveground growth of trees relative to those grown in impervious pavement settings. However, this was dependent on the absence of a gravel base and subgrade compaction. This research provided a glimpse into porous pavement's effect on Platanus orientalis, a hardy species often planted as a street tree. More research is required to determine whether the results found here are applicable in varying climates or for different tree species planted in different soil types, and surrounded by various pavement widths and configurations, such as sidewalks, roads, or plazas. Given the increased installation of porous pavements in the urban environment, such future research would help explain the growth and survival of trees in the urban forest.

Acknowledgments. Funding for this research was provided by the New Zealand School of Forestry, TREE Fund, and the Auckland City Council. The authors wish to thank Lachlan Kirk, Nigel Pink, Joe Cartman, Alwyn Williams, and Lisa Kulczycki for assistance with field work.

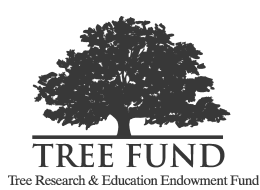

\section{LITERATURE CITED}

Anton, P.A. 2005. The Economic Value of Open Space. Wilder Research.

ASAE Standard EP542. 2002. Procedures for using and reporting data obtained with the soil cone penetrometer. St. Joseph, MI.

Berrang, P., D.F. Karnosky, and B.J. Stanton. 1985. Environmental factors affecting tree health in New York City. Journal of Arboriculture 11(6):185189.

Brown, L.J., and J.H. Weeber. 1992. Geology of the Christchurch Urban Area. Scale 1:25,000. Institute of Geological and Nuclear Sciences Limited, Lower Hutt, NZ.

Buhler, O., P. Kristoffersen, and S.U. Larsen. 2007. Growth of street trees in Copenhagen with emphasis on the effect of different establishment concepts. Arboriculture \& Urban Forestry 33(5):330-337.

Celestian, S.B., and C.A. Martin. 2004. Rhizosphere, surface, and air temperature patterns at parking lots in Phoenix, Arizona, U.S. Journal of Arboriculture 30(4):245-252.

Craul, P.J. 1985. A description of urban soils and their desired characteristics. Journal of Arboriculture 11(11):330-339.

Dunster, J.A. 1998. The role of arborists in providing wildlife habitat and landscape linkages throughout the urban forest. Journal of Arboriculture 24:160-167.

Ferguson, B.K. 2005. Porous Pavements. Taylor and Francis Group, New York. $600 \mathrm{pp}$.

Fostad, O., and P.A. Pedersen. 1997. Vitality, variation, and causes of decline of trees in Oslo center (Norway). Journal of Arboriculture 23(4):155-165.

Gartner, J.T., T. Treiman, and T. Frevert. 2002. Missouri urban forest: A ten-year comparison. Journal of Arboriculture 28(2):76-83.

Graves, W.R. 1994. Urban Soil Temperatures and their Potential Impact on Tree Growth. Journal of Arboriculture 20(1):24-27.

Heckel, P.F. 2004. Using trees to mitigate pollution. In: Air and Waste Management Association's Annual Meeting and Exhibition. pp. 4019-4031.

Iakovoglou, V., J. Thompson, L. Burras, and R. Kipper. 2001. Factors related to tree growth across urban-rural gradients in the Midwest, USA. Urban Ecosystems 5:71-85.

Jim, C.Y. 1997. Roadside trees in urban Hong Kong: Part III — Tree size and growth space. Arboricultural Journal 21:73-88. 
Kjelgren, R., and J.R. Clark. 1994. Urban microclimates and growth of sweetgum street trees. Arboricultural Journal 18:401-417.

Kjelgren, R., and T. Montague. 1998. Urban tree transpiration over turf and asphalt surfaces. Atmos. Environ. 32(1):35-41.

Kopinga, J. 1991. The effects of restricted volumes of soil on the growth and development of street trees. Journal of Arboriculture 17(3):57-63.

Long-Sheng, M., G. Yong, and S. Wen-Quan. 1993. Influences of street tree systems on summer micro-climate and noise attenuation in Nanjing City, China. Arboricultural Journal 17:239-251.

Macdonald, J.D., L.R. Costello, and T. Berger. 1993. An evaluation of soil aeration status around healthy and declining oaks in an urban environment in California. Journal of Arboriculture 19(4):209-219.

Marini, R.P. 2003. Approaches to Analyzing Experiments with Factorial Arrangements of Treatments Plus Other Treatments. HortScience 38(1):117-120.

Marosz, A., and J.S. Nowak. 2008. Effect of salinity stress on growth and macroelements uptake of four tree species. Dendrobiology 59:23-29.

McGann, R.P. 1983. The Climate of Christchurch. Edited by the Ministry of Transport. New Zealand Meteorological Service.

McPherson, E.G. 1994. Using urban forests for energy efficiency and carbon storage. Journal of Forestry 92:36-41.

Morgenroth, J., and G.D. Buchan. 2009. Soil moisture and aeration beneath pervious and impervious pavements. Arboriculture \& Urban Forestry 35(3):135-141.

Nicholson, G. 1984. Methods of soil, plant and water analysis. Forest Research Institute. Bulletin No. 70.

Philip, E., and Y.N. Azlin. 2005. Measurement of soil compaction tolerance of Lagestromia speciosa (L.) Pers. using chlorophyll fluorescence. Urban Forestry and Urban Greening 3(3-4):203-208.

Quigley, M.F. 2004. Street trees and rural conspecifics: Will long-lived trees reach full size in urban conditions? Urban Ecosystems 7(1):29-39.

R Development Core Team. 2008. R: A Language and Environment for Statistical Computing. R Foundation for Statistical Computing, Vienna, Austria.

Raeside, J.D. 1974. Soil Map of Christchurch Region, New Zealand. scale $1: 63,360$.

Roberts, B.R. 1977. The response of urban trees to abiotic stress. Journal of Arboriculture 3(4):75-78.

Schröder, K. 2008. Root space underneath traffic lanes. Arboricultural Journal 31(1):33-43.

Sinnett, D., G. Morgan, M. Williams, and T.R. Hutchings. 2008. Soil penetration resistance and tree root development. Soil Use and Management 24(3):273-280.

Smiley, E.T., L. Calfee, B.R. Fraedrich, and E.J. Smiley. 2006. Comparison of structural and noncompacted soils for trees surrounded by pavement. Arboriculture \& Urban Forestry 32(4):164-169.

Smith, K.D., May, P.B., and Moore, G.M. 2001. The influence of compaction and soil strength on the establishment of four Australian landscape trees. Journal of Arboriculture 27(1):1-7.

Su, Y.W., and M.J. Sun. 2006. Photosynthetic rates and antioxidant enzyme activity of Platanus occidentalis growing under two levels of air pollution along the streets of Seoul. Journal of Plant Biology 49(4):315-319.

Tennis, P.D., M.L. Leming, and D.J. Akers. 2004. Pervious Concrete Pavements. Portland Cement Association and the National Ready Mixed Concrete Association. 28 p.

Whitlow, T.H., and N.L. Bassuk. 1988. Ecophysiology of urban trees and their management - The North American experience. HortScience 23(3):542-546.

Xiao, Q., E.G. McPherson, J.R. Simpson, and S.L. Ustin. 1998. Rainfall interception by Sacramento's urban forest. Journal of Arboriculture 24:235-243.
Justin Morgenroth (corresponding author)

University of Canterbury

New Zealand School of Forestry

Private Bag 4800, Christchurch 8140

New Zealand

\section{Rien Visser}

University of Canterbury

New Zealand School of Forestry

New Zealand

Résumé. L'intégration d'arbres matures en santé au sein des environnements pavés en milieu urbain constitue un défi pour les forestiers urbains du fait que les surfaces imperméables sont associées avec une croissance et un taux de survie moindre des arbres. Il est connu que les surfaces poreuses peuvent diminuer ce problème en raison de leur perméabilité à l'air et à l'eau. Les auteurs de l'étude qui suit ont testé pourquoi les surfaces pavées poreuses affectent la croissance des arbres par rapport à celles imperméables en mesurant la croissance de la portion au-dessus du sol des arbres traités avec un facteur progressivement accru en terme d'arrangement au niveau du design et des types de divers profils de surfaces pavées. Cinquante semis de platanes orientaux (Platanus orientalis) ont été distribués également parmi les unités-témoin ou l'un des quatre traitements. Les unités traitées étaient caractérisées soient par une surface pavée imperméable ou perméable de $2,3 \times 2,3 \mathrm{~m}$, et la fondation sous la surface était composée soit par un loam sablonneux fin ou encore une fondation en gravier et une sous-fondation compactée, le tout afin de représenter deux designs de profils de surfaces pavées. Les résultats ont donné une croissance en hauteur et en diamètre accrue de la tige principale de même qu'une biomasse accrue dans le cas des surfaces pavées perméables. La croissance accrue par les surfaces pavées poreuses était atténuée lorsque le design du profil était composé d'une sous-fondation compactée et d'une fondation en gravier.

Zusammenfassung. Die Integration von gesunden, ausgewachsenen Bäumen in eine gepflasterte Umgebung ist eine spannende Herausforderung für urbane Forstleute, insbesondere weil versiegelnde Pflasterung mit Einschränkungen für Baumwachstum und Überleben verbunden wird. Es besteht die Annahme, daß eine offene Pflasterung diese Probleme mindert, indem sie größere Wasser- und Luftdurchlässigkeit bietet. Die Autoren der vorliegenden Studie testeten durch Messungen des oberirdischen Wachstums von Bäumen, die in größeren Arrangements von Pflasterprofil-Designs und Pflasterarten gepflanzt wurden, inwieweit sich poröse Pflasterbeläge im Vergleich zu versiegelnden Belägen das Baumwachstum beeinflussen. 50 Platanensämlinge wurden gleichmässig auf Kontrollflächen oder eine von vier Versuchsflächen gepflanzt. Die Versuchsflächen waren charakterisiert durch entweder poröse oder dichte Pflasterbelege von 2,3 X 2,3 m und hatten entweder feinen Sand oder ein Feinschotterbett und einen kompakten Unterbau, welches zwei Pflasterprofil-Designs reflektiert. Die Ergebnisse zeigen mehr Baumhöhe, Durchmesser und Biomasse aufgrund der offenen Pflasterung. Größeres Wachstum durch poröse Pflaster wurde durch Profil-Design einschl. kompakten Unterbau und Schotterbasis wieder ausgeglichen.

Resumen. La integración de árboles maduros saludables en ambientes pavimentados es una tarea desafiante para los dasónomos urbanos, en la medida que los ambientes impermeables están asociados con reducido crecimiento y supervivencia del árbol. Se ha pensado que los pavimentos porosos pueden aliviar este problema debido a su permeabilidad al aire y al agua. Los autores del estudio probaron si los pavimentos porosos afectan el crecimiento del árbol en relación a pavimentos impermeables mediante la medición del crecimiento en árboles tratados con un arreglo factorial de diseños de perfiles pavimentados y tipos de pavimentos. Cincuenta brinzales de plátanos orientales (Platanus orientalis) fueron distribuidos en parcelas de control y cuatro tratamientos. Las parcelas tratadas fueron caracterizadas para pavimentos porosos o impermeables de $2.3 \mathrm{~m}$ x $2.3 \mathrm{~m}$, y dos perfiles de suelos diseñados para suelo fino limo-arenoso o grava. Los resultados muestran crecimiento de la altura, diámetro y biomasa como un efecto de pavimentos porosos. El mayor crecimiento relacionado para pavimentos porosos fue negativo para perfiles con capas compactadas y base de grava. 